\title{
Virus Nipah
}

\author{
Novie H. Rampengan \\ Bagian Ilmu Kesehatan Anak \\ Fakultas Kedokteran Universitas Sam Ratulangi Manado \\ Email: novierampengan@yahoo.com
}

\begin{abstract}
Nipah virus caused outbreaks in Malaysia and Singapore in 2009 with a high mortality rates. It also erupted in Bangladesh, India, and the Philippines. Nipah virus infection varies from asymptomatic to severe manifestation with a mortality rate varies from $38 \%$ to $80 \%$. Diagnosis can be confirmed by using reverse transcriptase-polymerase chain reaction (RT-PCR), immunohistochemical examination, enzyme-linked immunosorbent assay (ELISA), and neutralization test. There is still neither vaccine nor specific treatment for the Nipah virus so far

Keywords: Nipah virus, signs and symptoms, diagnosis

Abstrak: Virus Nipah menimbulkan outbreak di Malaysia dan Singapura tahun 2009 dengan angka kematian yang tinggi. Selain itu virus Nipah juga menimbulkan outbreak di Bangladesh, India, dan Filipina. Infeksi virus Nipah dapat bervariasi dari asimtomatik sampai bermanifestasi klinis yang berat dengan angka kematian bervariasi dari 38\%-80\%. Diagnosis dapat ditegakkan dengan reverse transcriptase-polymerase chain reaction (RT-PCR), pemeriksaan imunohistokimia, enzyme-linked immunosorbent assay (ELISA), dan tes netralisasi. Sampai saat ini belum ada vaksin dan terapi spesifik untuk virus Nipah.
\end{abstract}

Kata kunci: virus Nipah, gejala, diagnosis

Pada tahun 2009 di Malaysia dan Singapura ditemukan adanya angka kejadian penderita demam yang disertai dengan gejala ensefalitis dan radang saluran napas pada pekerja peternakan babi atau rumah potong hewan babi di kedua negara tersebut. $^{1-3}$ Penelitian selanjutnya antar kedua negara tersebut dan Australia menunjukkan radang otak atau ensefalitis tersebut disebabkan oleh suatu jenis virus baru dari kelompok paramyxovirus. Dari penelitian retrospektif ternyata didapatkan babi sebagai sumber penularan ke manusia. ${ }^{3}$

Secara keseluruhan di Malaysia dilaporkan terdapat 257 kasus dengan 105 kematian (angka kematian 39\%), sedangkan di Singapura terdapat 11 kasus dengan 1 kematian (angka kematian 10\%). ${ }^{4}$ Selain itu dilaporkan terjadi 8 kali outbreak di
Bangladesh, 3 kali outbreak di India dan terakhir dilaporkan terjadi outbreak di Filipina. $^{5}$

\section{Epidemiologi}

Berdasarkan survei yang dilakukan pada para tenaga kesehatan (perawat dan dokter) yang merawat para pasien di Malaysia dan Singapura, virus ini ternyata ditularkan kepada manusia melalui kontak dengan babi yang terinfeksi dan masuk ke saluran pernapasan secara aerosol. Sampel yang disurvei (umumnya laki-laki dewasa) yaitu para anggota keluarga pasien, pekerja peternakan dan rumah potong hewan, para anggota militer yang terlibat dalam operasi pemusnahan ternak babi serta staf kedokteran hewan yang mungkin terpapar. $^{1-4}$

Telah dilaporkan terjadinya 8 kali 
outbreak virus Nipah di Bangladesh sejak tahun 2001-2004 dan di India terjadi 3 kali outbreak sejak tahun $2001 .^{6,7}$ Rerata kematian $70 \%-80 \%$ dari total pasien, dengan mayoritas pasien ialah petugas kesehatan atau kerabat pasien, sehingga hal ini mengindikasikan adanya transmisi dari manusia ke manusia dan menunjukkan derajat bahaya epidemik dari virus Nipah ini. ${ }^{5-7}$

Faktor risiko terinfeksi virus Nipah meliputi kontak dekat dengan babi yang telah terinfeksi virus tersebut. Virus ini juga mempunyai kemampuan tinggi untuk menimbulkan penyakit setelah menginfeksi penderita bila dibandingkan dengan virus Japanese Encephalitis (JE). 1,3,4

\section{Etiologi}

Virus Nipah merupakan suatu virus ribonucleic acid (RNA), termasuk dalam kelompok paramyxovirus dan genera morbili virus. Virus Nipah mempunyai kemiripan dengan virus Hendra sehingga virus ini pada tahap awal disebut sebagai Hendra-like virus, dan juga disebut sebagai equine morbili virus. ${ }^{1,3,4,8}$

Reservoir alami untuk virus Nipah ialah kelelawar buah (Pteropus Vampyrus dan Pteropus hypomelanus) yang hidup tersebar hampir di seluruh dunia. Pertama kali diketahui saat terdeteksi adanya RNA virus Nipah dalam tubuh kelelawar tersebut di Ghana. Babi tertular dari aerosol binatang yang terinfeksi virus Nipah, memakan buah-buahan yang terkontaminasi air liur, feses atau urin dari kelelawar yang terinfeksi virus Nipah maupun secara langsung lewat feses ataupun urin kelelawar yang terinfeksi virus Nipah. ${ }^{1,3,4,8}$

Awalnya virus ini ditemukan di daerah aliran sungai Nipah di negara bagian Negri Sembilan di Malaysia sehingga dikenal sebagai virus Nipah. Virus ini dapat menyebabkan suatu penyakit mulai dari yang ringan hingga kematian pada babi, tetapi juga dapat menjangkiti hewan lain seperti kucing dan anjing serta manusia yang berkontak dekat dengan babi terinfeksi virus ini. ${ }^{1,3,4}$

Pada pembiakan dengan jaringan sel
Vero, virus ini dengan cepat membentuk formasi sinsitia. Pada pemeriksaan immunofluorescense assay dengan cairan asites hiperimun dari tikus, ternyata jaringan sel Vero yang terinfeksi menunjukkan reaksi positif terhadap antibodi terhadap virus Hendra, tetapi negatif terhadap berbagai jenis virus lain yang dapat menyebabkan radang otak. Hal tersebut mengindikasikan bahwa virus ini berasal dari kelompok yang sama dengan virus Hendra meskipun tidak identik. ${ }^{1,3,4}$

Pemeriksaan urutan nukleotida menunjukkan bahwa virus Nipah mempunyai $90 \%$ homologi dengan virus Hendra. Dengan berhasilnya diisolasikan virus ini, maka dapat di buat suatu assay antibodi untuk pemeriksaan IgM dan IgG di berbagai cairan tubuh terhadap virus Nipah. ${ }^{1,3-5}$

\section{Gejala klinis}

Masa inkubasi infeksi virus Nipah umumnya 3-14 hari (2 hari-bulan), meskipun terdapat laporan pasien yang menyebutkan kontak dengan babi yang sakit 11 tahun sebelumnya. Beberapa pasien dengan infeksi virus Nipah bersifat asimtomatik atau ringan, namun umumnya gejala awal seperti influenza berupa sakit kepala atau pusing yang diikuti dengan demam, sakit kepala, nyeri menelan, mialgia, muntah, dan batuk tidak produktif namun dapat diikuti gejala ensefalitis yang disertai gejala neurologik seperti drowsiness, mengantuk, kejang, koma, bahkan bisa juga segmental mioklonus. Gejala-gejala yang dilaporkan secara kelompok ialah: $:^{1,3-5}$

a. Demam yang biasanya terjadi secara mendadak. ${ }^{1,3,4}$

b. Gejala saluran pernapasan dimana pada sebagian pasien didapatkan adanya gejala radang saluran pernapasan seperti batuk yang tidak produktif menyerupai keaadaan flu berat dengan manifestasi pneumonitis. Gejala pernapasan yang lain seperti hipoventilasi dan hiperkapnia, dan hal ini dapat disertai dengan gangguan pernapasan yang berat 
sehingga memerlukan alat bantu napas. Pada gambaran foto paru dapat terlihat adanya bintik granuler atau infiltrat pada lapang paru. Beberapa pasien bisa mengalami gangguan pernapasan seperti pneumonia atipikal atau acute respiratory distress syndrome (ARDS). ${ }^{5}$

Di Bangladesh gejala gangguan pernapasan berat sering ditemukan, dimana $62 \%$ pasien mempunyai batuk, $69 \%$ mengalami kesulitan bernapas dan ditemukan adanya infeksi yang luas pada kedua lapangan paru serta angka kematian sebesar $73 \%$, ${ }^{9}$ sedangkan di Malaysia didapatkan $14 \%$ pasien mengalami batuk tidak produktif, $6 \%$ mempunyai paru abnormal namun umumnya ringan dan bersifat setempat dengan angka kematian sebesar $39 \%$. $^{10}$

c. Gejala susunan saraf umumnya dimulai dengan sakit kepala, rasa mengantuk, gangguan orientasi seperti bingung, kaku kuduk serta kejang (25\% kasus). Termasuk gejala neurologik yang pernah dilaporkan ialah gangguan fungsi serebelar seperti gangguan berjalan, kehilangan keseimbangan tubuh, dismetri dari kedua tungkai serta disdiakokinesia. Juga dilaporkan hilangnya refleks tendon, diikuti adanya reflex patologik Babinski yang positif, paresis dari mono hingga kuadriparesis, ataksia, sindroma Homer, halusinasi visual serta audiologis. Juga dilaporkan adanya gangguan bicara (disfoni), gangguan penglihatan, mioklonus serta kelumpuhan otot abdusens. Gambaran keterlibatan SSP biasanya merupakan gambaran keterlibatan batang otak. Gejala-gejala neurologik dapat menjadi berat sehingga terjadi kondisi koma (60\% kasus) dalam waktu 24-48 jam serta pasien dapat mengalami hipertensi berat, peningkatan curah jantung dan demam tinggi sehingga umumnya memerlukan ventilasi mekanik. Beberapa pasien mengalami relaps ensefalitis atau late onset encephalitis. ${ }^{1,3-5} \mathrm{Di}$ Bangladesh ditemu-kan 1/3 kasus mempunyai gangguan neurologik sesudah 7-30 bulan terinfeksi. ${ }^{11}$ d. Gejala-gejala lainnya meliputi hilangnya nafsu makan, mual, muntah, nyeri otot tubuh (mialgia). ${ }^{1,3,4}$

\section{Patofisiologi}

Dijumpai gambaran patologik yang sesuai dengan infeksi virus pada neuron dan kerusakan endotel serta vaskulitis sebagian besar pada arteriola, pembuluh kapiler serta venula, meski juga dapat dijumpai pada pembuluh darah yang besar di berbagai organ tubuh. ${ }^{1,3,4}$

Kelainan terberat dari gambaran patologik ini dijumpai pada otak namun dapat juga dijumpai pada organ lain seperti paru, jantung, dan ginjal. Keadaan ini menimbulkan suatu penyakit SSP yang luas akibat vaskulitis yang nekrotik serta formasi sinsitia yang berbeda dengan gambaran enseomielitis sesudah infeksi dengan virus yang lain, meskipun terdapat beberapa kesamaan dengan gambaran radang otak akibat infeksi virus Hendra. ${ }^{1,3,4}$

Kerusakan pembuluh darah yang terjadi berupa peradangan dan nekrosis dinding pembuluh darah, adanya trombosis disertai infiltrasi sel-sel radang berupa netrofil dan monosit, serta micro-infarct dengan gambaran iskemi jaringan di sekitar pembuluh darah yang mengalami vaskulitis. Dijumpai pula formasi sinsitia pada endotel dari otak, paru, serta kapsula Bowman dari glomerulus ginjal. 1,3,4

Pada otak terjadi penyebaran (inklusi) sitoplasmik eosinofil serta nukleus virus pada neuron yang dekat dengan pembuluh darah yang mengalami peradangan (vaskulitis) seperti yang sering dijumpai pada infeksi dengan virus paramyxovirus lainnya. Juga dijumpai area fokal dengan neuronofagia serta pembentukan nodulmikroglia. $1,3,4$

Gambaran pembengkakan perivaskuler serta meningitis biasanya ringan dan tak dijumpai adanya demielinisasi perivaskuler. Kejadian vaskulitis serta micro-infarct dengan iskemi pada otak tersebar secara acak melibatkan baik substansia grisea maupun alba dari serebelum, ganglia basal, medulla 
oblongata, serta medula spinalis. ${ }^{1,3,4}$

\section{Pemeriksaan penunjang}

Pada pemeriksaan darah diperoleh jumlah lekosit normal atau lebih rendah, dan pada beberapa pasien dapat ditemukan trombositopenia. Pada salah satu pasien didapatkan gangguan elektrolit berupa hiponatremia serta sindroma gangguan sekresi anti-diuretic hormone (IADH), ${ }^{1,3,4}$

Pemeriksaan virus Nipah bisa diperoleh dari darah, tenggorokan, atau nasal swabs, cairan serebrospinalis, urin, dan jaringan post mortem. Isolasi virus dengan identifikasi RNA menggunakan reverse transcriptase-polymerase chain reaction ( $\mathrm{RT}-\mathrm{PCR}$ ), deteksi antigen dengan antibodi spesifik menggunakan pewarnaan imunohistokimia dari jaringan post mortem yang dapat diidentifikasi terutama dari SSP diikuti paru atau ginjal. Tes serologik menggunakan metode tidak langsung yaitu enzyme-linked immunosorbent assay (ELISA), dan tes netralisasi. ${ }^{5}$

Pada pemeriksaan cairan serebrospinal biasanya dijumpai peningkatan kadar protein serta jumlah sel darah putih (limfosit ataupun polimorfonuklear). Gambaran foto paru sering menunjukkan adanya bintik granuler atau infiltrat pada lapang paru. Pemeriksaan elektroensefalogram (EEG) dijumpai adanya gambaran perlambatan aktivitas elektrik otak yang menyeluruh, meski hal ini tidak berlangsung terus menerus dan kadang dapat dijumpai aktivitas listrik yang sesuai dengan kondisi epilepsi. ${ }^{1,3,4}$

Pada pemeriksaan magnetic resonance imaging (MRI) dilaporkan adanya beberapa lesi dengan gambaran hiperintens tersebar yang merupakan gambaran serebritis, serta lesi-lesi fokal yang tersebar, berbeda dengan infeksi JE yang umumnya lebih melibatkan bagian talamus, ganglia basal, hipokampus, dan batang otak. ${ }^{1,3,4}$

\section{Diagnosis}

Berdasarkan anamnesis berpergian ke daerah endemis virus Nipah atau terpapar dengan hewan babi yang terinfeksi virus
Nipah, gejala klinis yang ada menyokong ke infeksi virus Nipah dan pemeriksaan laboratorium yang mendukung adanya infeksi virus Nipah. Diagnosis virus Nipah bisa disalah diagnosis dengan JE, namun dapat dibedakan berdasarkan ada tidaknya riwayat vaksinasi JE sehingga pasien akan terlindungi dari infeksi JE dan umumnya virus Nipah ditemukan kasus pada orang dewasa sedangkan JE tidak demikian. ${ }^{1,3-5}$

\section{Penyulit}

Dapat ditemukan penyulit seperti septikemia, perdarahan saluran cerna dan gangguan ginjal. Adanya gejala sisa (sequele) seperti kejang, perubahan/ gangguan kepribadian serta gejala psikiatri seperti halusinasi juga telah dilaporkan. ${ }^{1,3-5}$

\section{Pengobatan}

Tidak terdapat terapi definitif untuk infeksi virus Nipah. Obat antivirus ribavirin menunjukkan aktivitas in vitro tetapi hasil penggunaannya pada pasien tidak memberikan jawaban yang pasti bahwa penggunaan obat ini bermanfaat. Pemberian dosis tinggi obat ini secara intravena banyak disertai efek samping yang berat sehingga pemberiannya harus diamati dengan baik. Pada beberapa kasus di Singapura dipergunakan pengobatan empiris dengan asiklovir dan seftriakson. $1,3-5$

\section{Pencegahan}

Upaya pencegahan yang dapat dilakukan antara lain ialah menghindari kontak (terutama saliva) dengan hewan atau pasien yang terinfeksi atau menggunakan alat serta pakaian pelindung yang sesuai bila kontak ini tak dapat dihindari. Tidak ada vaksin untuk virus Nipah sampai saat ini, namun uji coba yang menggunakan protein Hendra virus pada monyet hijau di Afrika menunjukkan adanya proteksi terhadap virus Nipah. ${ }^{12}$ Deteksi dini kasus merupakan kunci usaha pencegahan untuk menghindari penyebaran lebih lanjut. ${ }^{1,3-5}$ 
Usaha penanggulangan kejadian luar biasa (KLB) di Malaysia dan Singapura berhasil dilakukan dengan pemusnahan 890.000 ternak babi, penyuluhan masyarakat mengenai kontak dengan babi, penggunaan alat-alat (seperti masker dan sarung tangan), pakaian pelindung bagi individu yang mungkin akan terpapar dan penutupan rumah potong hewan babi. Dilakukan pula suatu sistem surveilans dan kontrol nasional terhadap kasus dan hewan yang mungkin terinfeksi. ${ }^{1,3,4}$

\section{Simpulan}

Virus Nipah mempunyai reservoir kelelawar buah yang hampir terdapat di seluruh dunia. Penularan terjadi penularan dari kelelawar buah tersebut ke babi maupun binatang lainnya dan manusia lewat urin dan feses yang terkontaminasi. Diduga terdapat penularan dari manusia ke manusia. Sampai saat ini belum ada vaksin dan terapi spesifik untuk virus Nipah.

\section{DAFTAR PUSTAKA}

1. Lee KE, Umapathi T, Tan CB, Tjia HTL, Chua TS, Oh HML, et al. The neurological manifestations of virus Nipah encephalitis, a novel Paramyxovirus. Ann Neurol. 1999;46(3):428-32.

2. Paton NI, Lee YS, Auchus AP, Lee KE, Ling AE, Chew SK, et al. Outbreak of Nipah virus among abattoir workers in Singapore. Lancet 1999;354:1253-6.

3. Soedarma SP, Garna H, Hadinegoro SR, Satara IH. Virus Nipah. In: Soedarma SP, Garna H, Hadinegoro SR, Satara IH, editors. Buku Ajar Infeksi dan Pediatri Tropis (2nd ed).
Jakarta: Badan Penerbit IDAI, 2008; p. 292-5.

4. Centers for disease control/morbidity and mortality weekly report. Update outbreak of Nipah virus Malaysia and Singapore. MMWR weekly. 1999;48(16):335-7.

5. The center for food securities and public health. Nipah virus infection. Iowa State University, 2016; p. 1-9.

6. Bangladesh Institute of Epidemiology, Disease, Control and Research. Nipah outbreak at Lalmonirhat, 2014.

7. Chadha MS, Comer JA, Lowe L. Nipah virus associated encephalitis outbreak Siliguri, India. Emerg Infect Dis. 2006;12(2):235-40.

8. Drexler JF, Corman VM, Gloza-Rausch F, Seebens A, Annan A. Henipavirus RNA in African bats. PLoS ONE 2009;4(7):e6367.

9. Hossain MJ, Gurley ES, Montgomery JM, Bell M, Carroll DS, Hsu VP, et al. Clinical presentation of nipah virus infection in Bangladesh. Clin Infect Dis. 2008;46:977-84.

10. Goh KJ, Tan CT, Chew NK, Tan PS, Kamarulzaman A, Sarji SA, et al. Clinical features of Nipah virus encephalitis among pig farmers in Malaysia. N Engl J Med. 2000;342:1229-35.

11. Sejvar JJ, Hossain J, Saha SK, Gurlev ES, Banu S, Hamadani JD, et al. Long-term neurological and functional outcome in Nipah virus infection. Ann Neurol. 2007;62:23542.

12. Bossart KN, Rockx B, Feldmann F, Brining $D$, Scott $D$, LaCasse $R$, et al. A Hendra virus $G$ glycoprotein subunit vaccine protects African green monkeys from Nipah virus challenge. Science Translat Med. 2012;4(146):146ra107. 